\title{
Influence of Water Vapor and Temperature on the Oxide Scale Growth and Alpha-Case Formation in Ti-6Al-4V Alloy
}

\author{
B. Öztürk ${ }^{1}$ - L. Mengis ${ }^{1} \cdot$ D. Dickes ${ }^{2} \cdot$ U. Glatzel ${ }^{2} \cdot$ M. C. Galetz ${ }^{1}$
}

Received: 30 July 2021 / Revised: 20 October 2021 / Accepted: 2 November 2021 /

Published online: 24 November 2021

(c) The Author(s) 2021

\begin{abstract}
The Ti-6Al-4V alloy is extensively used in aerospace, automotive and biomaterial applications. In the aerospace industry, the service temperature of Ti-6Al-4V is currently limited to $350{ }^{\circ} \mathrm{C}$ due to its insufficient oxidation resistance. Oxidation at higher temperatures causes the formation of a fast-growing oxide scale and an oxygen-enriched subsurface layer, which is known as the "alpha-case." Additionally, the effect of water vapor on the oxidation behavior is critical. In the present study, the oxidation behavior of Ti-6Al-4V in dry air and air containing $10 \mathrm{vol} . \% \mathrm{H}_{2} \mathrm{O}$ at 500,600 and $700{ }^{\circ} \mathrm{C}$ for up to $500 \mathrm{~h}$ has been investigated. The main focus of this study is the examination of the different oxide scale morphologies along with the oxygen enrichment in the subsurface zone. It has been observed that spallation of the oxide scale is more severe in a water vapor-containing environment. In dry air, the oxide morphology shows the typical layered $\mathrm{TiO}_{2} / \mathrm{Al}_{2} \mathrm{O}_{3}$ structure after exposure at $700{ }^{\circ} \mathrm{C}$ for $300 \mathrm{~h}$, while $\mathrm{Al}_{2} \mathrm{O}_{3}$ precipitates are present in the outermost part of the $\mathrm{TiO}_{2}$ scale when oxidized in wet air. This indicates that the solubility and diffusivity of $\mathrm{Al}^{3+}$ ions in $\mathrm{TiO}_{2}$ are influenced by water vapor. In addition, the extent of oxygen enrichment in the subsurface zone (alpha-case) as a function of temperature and time is determined by nanoindentation profiles. It was shown that in contrast to the scale formation, the alpha-case thickness is not affected by the presence of water vapor in the atmosphere.
\end{abstract}

Keywords Oxidation · $\alpha$-case formation · Oxygen diffusion zone $\cdot$ Water vapor · Defect chemistry

B. Öztürk

beyza.oeztuerk@dechema.de

1 DECHEMA Research Institute, Materials and Corrosion, Theodor-Heuss-Allee 25, 60486 Frankfurt am Main, Germany

2 University of Bayreuth, Metals and Alloys, Prof.-Rüdiger-Bormann-Str. 1, 95447 Bayreuth, Germany 


\section{Introduction}

Titanium and Ti alloys are used in numerous applications of the chemical, marine, aerospace and biomedical industries due to their outstanding properties, such as high specific strength-to-weight ratio, exceptional corrosion resistance and excellent biocompatibility [1]. Ti alloys are commonly chosen for fan blades and compressor components for aero-engine gas turbines [2, 3]. Ti-6Al-4V is the most frequently used titanium alloy and is known as the "workhorse" of the titanium industry [4]. The oxidation behavior of Ti alloys is generally characterized by the development of a thin oxide scale on the surface, in addition to the inward diffusion of oxygen into the bulk metal [5]. When titanium alloys are exposed to prolonged oxidation times, the oxide scale quickly loses its protective nature due to the reduced bonding strength between the oxide layer and substrate [2,5]. Additionally, various intermediate phases at the interface and a high solid solubility of oxygen in $\alpha$-titanium (i.e., about 33 at.\%) result in an oxygen-rich, continuous and hard layer below the oxide scale [2, 6-8]. Titanium metal has a high affinity for oxygen, which is an alpha-stabilizing element that leads to a larger alpha-phase fraction within the oxygen-rich subsurface zone [5, 9]. Consequently, this zone is referred to as the "alpha-case" [7]. Furthermore, oxygen causes hardening as well as embrittlement of titanium by interstitial solid solution strengthening [10].

The alpha-case has a negative effect on mechanical properties, such as ductility, fracture toughness and fatigue life [11]. Thus, alpha-case mitigation is crucial to the life cycle of titanium alloys [12]. The alpha-case tends to occur if titanium alloys are subjected to temperatures above $480{ }^{\circ} \mathrm{C}\left(\sim 0.4 \mathrm{~T}_{\mathrm{m}}\right)$ in oxygencontaining environments $[11,13]$. Currently, the maximum service temperature of Ti-6Al-4V is thus restricted to $350{ }^{\circ} \mathrm{C}$ [2]. Fundamentally understanding the oxidation mechanism, alpha-case formation and influence on mechanical properties could result in an even broader application space (higher temperatures) for these alloys or perhaps further property enhancement [5].

The high temperature behavior of Ti-6Al-4V in air has been studied by several researchers. Du et al. [14] detected alternating $\mathrm{Al}_{2} \mathrm{O}_{3}$ and $\mathrm{TiO}_{2}$ layers in the oxide scale of Ti-6Al-4V at different treatment temperatures ranging from 650 to $850{ }^{\circ} \mathrm{C}$. This has been attributed to the outward diffusion of aluminum and inward diffusion of oxygen [14]. Guleryuz and Cimenoglu [12] determined that the depth of the oxygen diffusion zone (ODZ) of Ti-6Al-4V increases with temperature and/or time in the oxidation temperature range of $600-800{ }^{\circ} \mathrm{C}$ for different time intervals ranging between 0.5 and $72 \mathrm{~h}$. Gaddam et al. [6] examined the alpha-case depth in Ti-6Al-4V which was isothermally treated at 593 and $700{ }^{\circ} \mathrm{C}$ up to $500 \mathrm{~h}$. After $500 \mathrm{~h}$ of exposure time, the alpha-case depth at 593 and $700{ }^{\circ} \mathrm{C}$ was found to be around 3 and $200 \mu \mathrm{m}$, respectively. All investigations indicate that the alpha-case depth increases with temperature and time. Additionally, the microhardness is higher in the alpha-case zone compared to the bulk [6] acting as a good indicator for the extent of oxygen enrichment.

The effect of water vapor on oxidation resistance is also critical, because water vapor can influence microstructure, mechanical properties, adhesion, and 
transport properties of oxide scales along with the mechanical properties of the bulk metal [15]. Motte et al. [16] compared the oxidation of Ti-6Al-4V and pure titanium in the temperature range of $650-950{ }^{\circ} \mathrm{C}$ in a water vapor environment. Observations showed that the oxide scale on Ti-6Al-4V consisted of a thin alumina sublayer between rutile layers over the temperature range of $750-900{ }^{\circ} \mathrm{C}$. With water vapor exposure, stress relaxation took place in the outer part of the scale through a recrystallization process, leading to a two-layered structure [16]. Wang et al. [17] conducted oxidation experiments of Ti-6Al-4V at temperatures between 600 and $800{ }^{\circ} \mathrm{C}$ for $4 \mathrm{~h}$ also in a water vapor environment. According to their study, growth of hard oxide layers and strain developed during the dissolution of oxygen beneath the oxide layer through the substrate led to a rise in microhardness with increasing exposure temperature [17].

Although the influence of water vapor on the oxidation behavior of Ti alloys was investigated in the above studies [16, 17], its exact influence on the oxide growth mechanism(s) as well as the alpha-case formation was not finally clarified. Therefore, a systematic investigation on the oxidation behavior of Ti-6Al-4V in synthetic air and synthetic air containing $10 \mathrm{vol} . \% \mathrm{H}_{2} \mathrm{O}$ at 500,600 and $700{ }^{\circ} \mathrm{C}$ for up to $500 \mathrm{~h}$ was carried out in the present study. The main focus of this research was examination of the oxide scale morphologies and oxygen enrichment in the subsurface zone to elucidate the fundamental mechanism(s).

\section{Materials and Experimental Methods}

Ti-6Al-4V ELI (max. 0.13 wt.\% oxygen, according to the ASTM F-136 Standard [18]) metal was used within this study because of its low concentration of interstitial elements, e.g., $\mathrm{O}$ and $\mathrm{N}$, compared to Ti-6Al-4V material, which is used in aerospace applications [19]. In this regard, $\mathrm{O}$ and $\mathrm{N}$ enrichment in the subsurface during oxidation can be easily identified. The initial chemical composition of the Ti-6Al-4V ELI material is given in Table 1. Prior to quasi-isothermal oxidation tests, $15 \times 10 \times 3 \mathrm{~mm}$ coupons were prepared. The recast layer from the machining on the surface of the coupons was removed by grinding down to P1200 finish using SiC abrasive papers. After that, coupons were cleaned with acetone in an ultrasonic bath for $10 \mathrm{~min}$ and dried by hot air.

The oxidation process of the Ti-6Al-4V coupons was carried out in synthetic air and synthetic air containing 10 vol.\% water vapor using a 6-zone furnace, which is displayed in Fig. 1. This furnace contains two cylindrical silica tubes and each tube is separated into 6 zones. The samples were placed in small alumina crucibles. The air was brought into one of the cylindrical tubes, whereas the water vapor was generated by a thermostat and introduced into the other

Table 1 Measured chemical composition of as-received Ti-6Al-4V ELI (wt.\%) by EDS

\begin{tabular}{lllll}
\hline Element & $\mathrm{Ti}$ & $\mathrm{Al}$ & $\mathrm{V}$ & $\mathrm{Fe}$ \\
\hline Chemical composition (wt.\%) & 84.72 & 6.73 & 5.02 & 0.35 \\
\hline
\end{tabular}




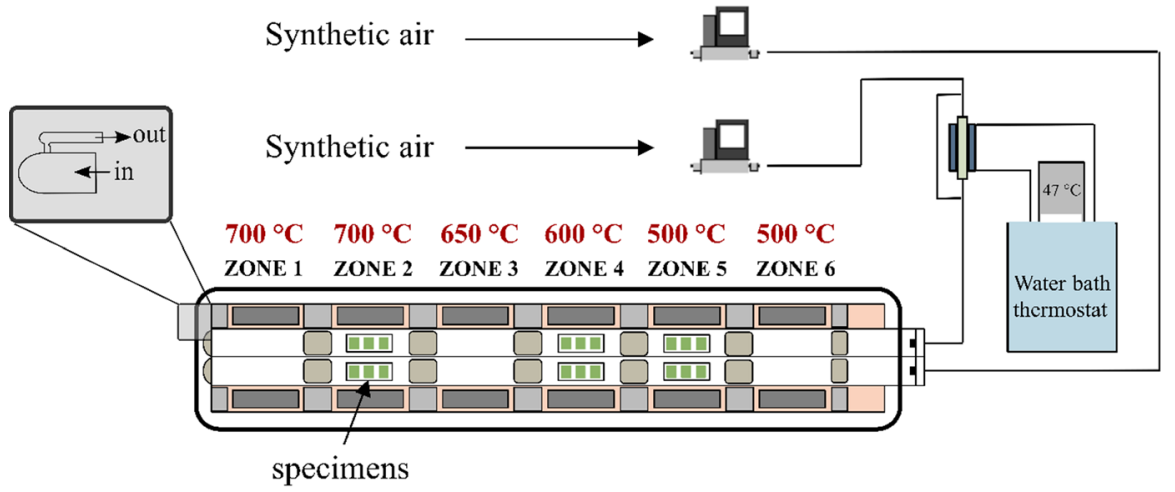

Fig. 1 Experimental setup for the oxidation under dry and moist atmospheres

cylindrical tube. The gas velocity was $6.8 \times 10^{-3} \mathrm{~m} / \mathrm{s}$. During oxidation, gas flow was kept constant at $80 \mathrm{ml} / \mathrm{min}$.

The quasi-isothermal oxidation experiments were conducted at 500, 600 and $700{ }^{\circ} \mathrm{C}$ for up to $500 \mathrm{~h}$. After oxidation, coupons were subjected to free cooling in the furnace. For all temperatures, 18 specimens were exposed for $100 \mathrm{~h}$. To determine mass gain and standard deviation, all the samples were removed from the furnace and massed. After the initial step, 6 samples were removed for investigation and the remaining 12 samples were oxidized for an additional $200 \mathrm{~h}$, before 6 samples were oxidized for the final $200 \mathrm{~h}$. Oxidized coupons were cleaned with acetone in an ultrasonic bath for 2 min and dried by hot air. The mass of the coupons was measured before and after the oxidation tests using an electronic balance (Mettler Toledo XP205DR) having an accuracy of $\pm 0.00001 \mathrm{~g}$.

In order to examine the cross-sectional microstructure, metallographic preparation of the coupons was performed. A dense layer of gold was sputtered on top of the specimen, and then nickel was galvanically deposited on the surface of the coupons to prevent severe oxide spallation from the surface during preparation. After that, the coupons were hot embedded into resin by using a Struers Labopress-3 mounting machine and polished with diamond suspension of $3 \mu \mathrm{m}$ and $1 \mu \mathrm{m}$, respectively.

Optical microscopy (OM, Leica DMC4500) was used for the investigation of the surface and cross section of the specimens. An SEM (Hitachi SU5000) was utilized for closer examination of the oxide scale morphologies. In addition, elemental mapping by electron microprobe analysis (EPMA, Jeol JXA-8100) was carried out to observe the element distribution in the oxide scale as well as in the subsurface zone. As a complementary investigation technique, nanoindentation measurements were conducted for the evaluation of the alpha-case thickness. In this paper, the Oliver and Pharr approach, which is a method for determining hardness from indentation load-displacement data, was utilized with a Berkovich indenter and a maximum load of $20 \mathrm{mN}$ [20]. 


\section{Results}

\section{Net Mass Change Analysis}

The net mass change per surface area $(\Delta \mathrm{m} / \mathrm{A})$ data as a function of oxidation time for samples heat-treated at 500,600 and $700{ }^{\circ} \mathrm{C}$ in dry air and air with 10 vol. $\% \mathrm{H}_{2} \mathrm{O}$ is presented in Fig. 2.

In dry air, oxidation caused spallation at $700{ }^{\circ} \mathrm{C}$ after $300 \mathrm{~h}$; accordingly, mass loss appeared at $700{ }^{\circ} \mathrm{C}$ after $500 \mathrm{~h}$ due to a severe spallation. In wet air, spallation was observed at a lower temperature of $600{ }^{\circ} \mathrm{C}$ after $300 \mathrm{~h}$ and sooner at $700{ }^{\circ} \mathrm{C}$ after only $100 \mathrm{~h}$. As a consequence, mass loss appeared after oxidation at $600{ }^{\circ} \mathrm{C}$ after $500 \mathrm{~h}$ and at $700{ }^{\circ} \mathrm{C}$ after $300 \mathrm{~h}$ in the presence of water vapor. Temperatures and time intervals showing spallation are marked with an asterisk (*) in Fig. 2.

\section{Morphology of the Oxide Scale}

\section{Investigation of the Surface}

The SEM images (secondary electron images) showing the surface morphologies of the Ti-6Al-4V after oxidation in both atmospheres are presented in Fig. 3. Although not explicitly shown within this study, oxide scales were also characterized by X-ray diffraction (XRD) at room temperature. Typical XRD patterns of the oxide scale developed after heat-treatment at $600{ }^{\circ} \mathrm{C}$ revealed that the oxide scale principally contained rutile-type $\mathrm{TiO}_{2}$ and $\alpha-\mathrm{Al}_{2} \mathrm{O}_{3}$. In both atmospheres, the surface of the specimens was covered with $\mathrm{TiO}_{2}$ (rutile) and $\alpha-\mathrm{Al}_{2} \mathrm{O}_{3}$ crystals.



Fig. 2 Net mass change in dry air and air with 10 vol. $\% \mathrm{H}_{2} \mathrm{O}$ 

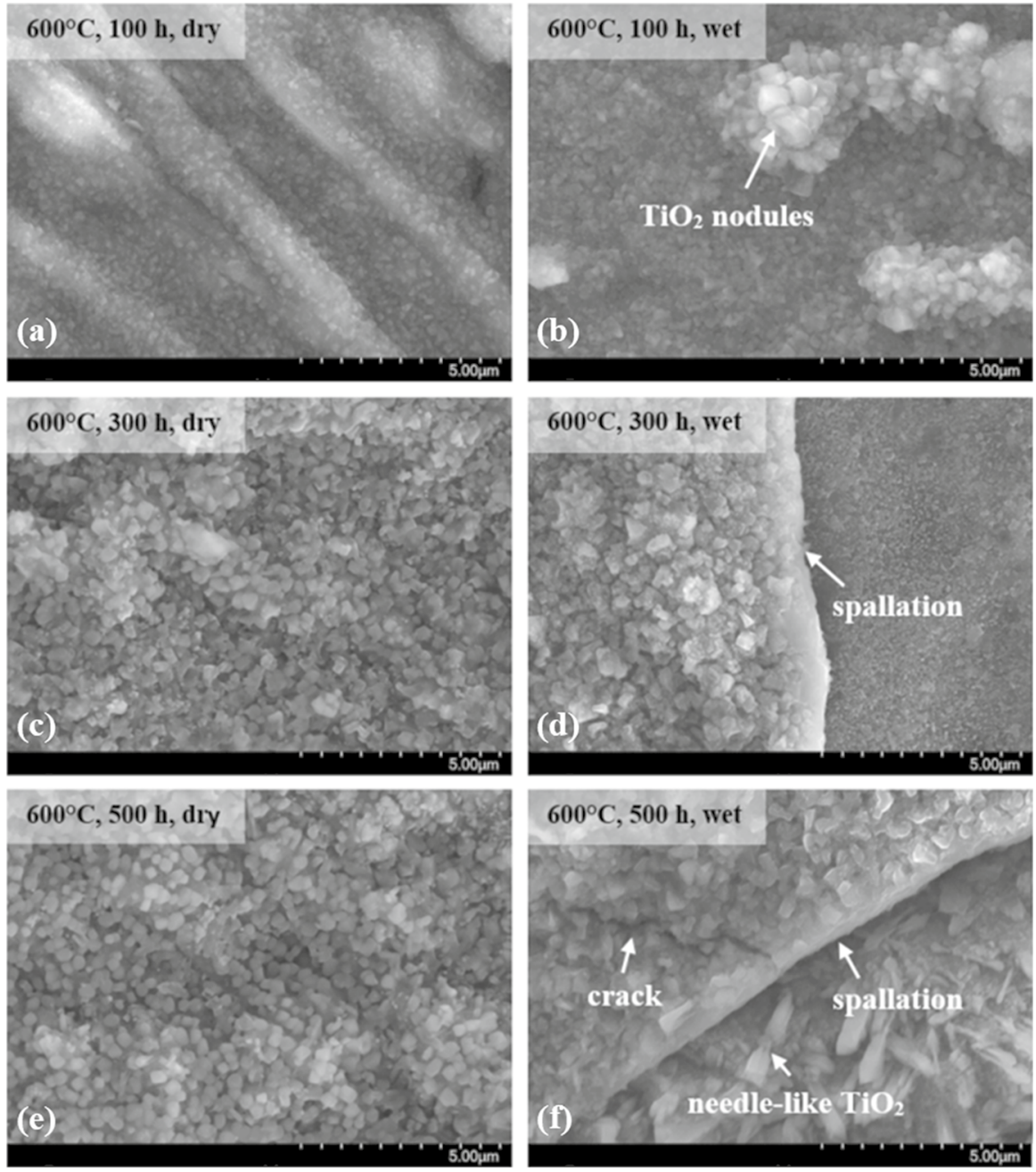

Fig. 3 Crystal morphology of outer oxide layer after oxidation at a $600{ }^{\circ} \mathrm{C}$ for $100 \mathrm{~h}$ in dry air b $600{ }^{\circ} \mathrm{C}$ for $100 \mathrm{~h}$ in wet air $\mathbf{c} 600{ }^{\circ} \mathrm{C}$ for $300 \mathrm{~h}$ in dry air d $600{ }^{\circ} \mathrm{C}$ for $300 \mathrm{~h}$ in wet air e $600{ }^{\circ} \mathrm{C}$ for $500 \mathrm{~h}$ oxidation in dry air $\mathbf{f} 600{ }^{\circ} \mathrm{C}$ for $500 \mathrm{~h}$ oxidation in wet air

The oxide scales showed fine grains after exposure at $500{ }^{\circ} \mathrm{C}$. Figure 3 also shows the characteristic morphologies of the surface oxide scale at $600{ }^{\circ} \mathrm{C}$. For short exposure times of $100 \mathrm{~h}$, the directionality from grinding was still evident in dry air. However, $\mathrm{TiO}_{2}$ nodules were formed in wet air due to the joining and growing of the crystals. Additionally, the presence of water induced oxide spallation after $300 \mathrm{~h}$ which led to an inhomogeneous and mixed crystal morphology of the oxide phases. The investigation of the surface oxide layer provided indication of cracking at $600{ }^{\circ} \mathrm{C}$ after $500 \mathrm{~h}$ in wet air. 


\section{Investigation of the Cross Section}

Metallographic cross sections did not indicate remarkable differences in oxide scale morphologies for oxidation temperatures up to $600{ }^{\circ} \mathrm{C}$. Figure 4 presents the SEM images (3D backscattered electron images) showing the cross sections of the oxidized specimens. The thickest portion of the oxide scale, where no oxide scale spallation was evident, was chosen for the metallographic cross section analysis. Figure $4 \mathrm{a}, \mathrm{b}$ shows the cross sections of the samples oxidized at $600{ }^{\circ} \mathrm{C}$ for $100 \mathrm{~h}$ in both atmospheres, where the outer part of the scale consists

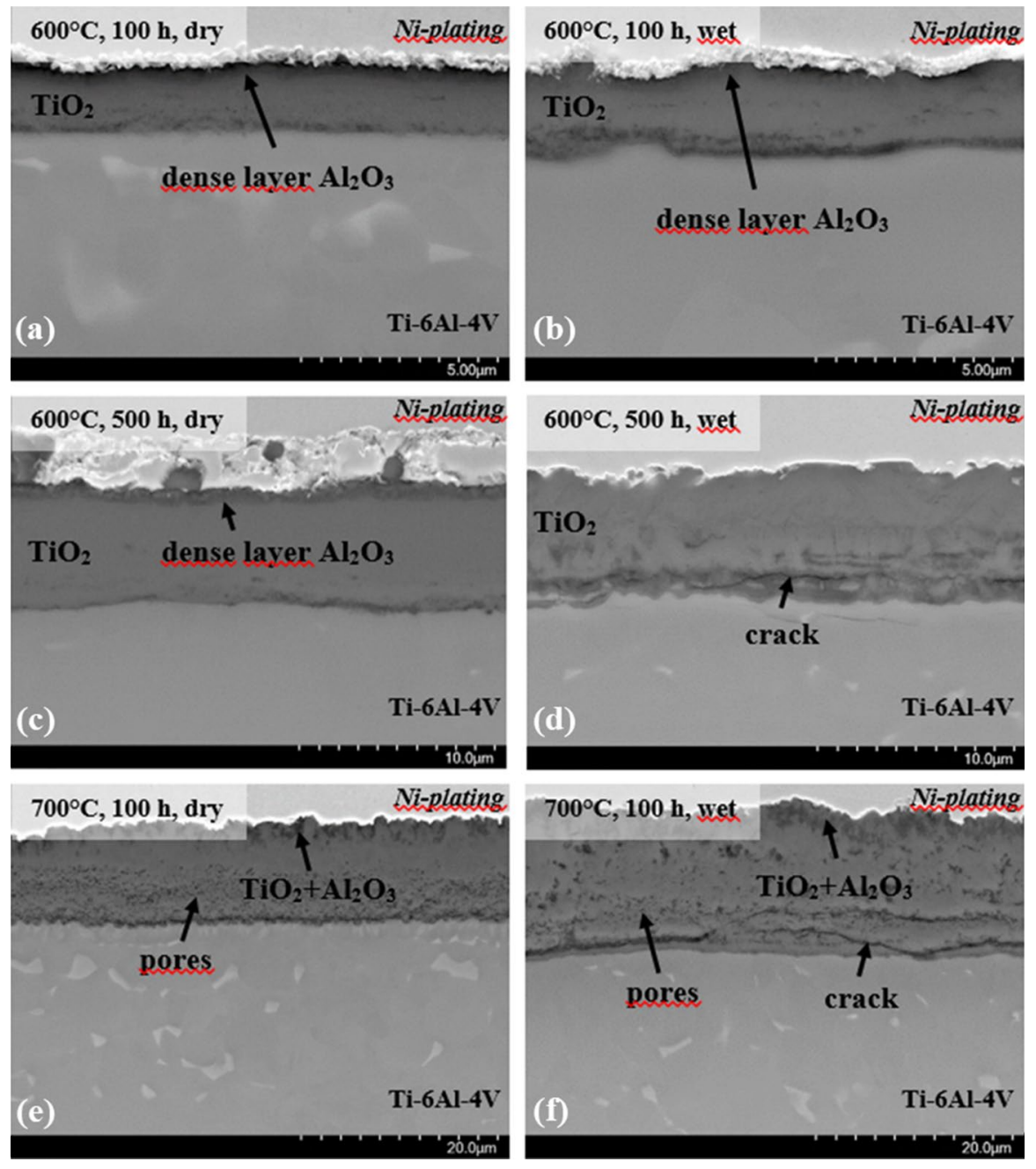

Fig. 4 Cross sections of oxide scales after oxidation at $\mathbf{a} 600{ }^{\circ} \mathrm{C}$ for $100 \mathrm{~h}$ in dry air $\mathbf{b} 600{ }^{\circ} \mathrm{C}$ for $100 \mathrm{~h}$ in wet air c $600{ }^{\circ} \mathrm{C}$ for $500 \mathrm{~h}$ in dry air d $600{ }^{\circ} \mathrm{C}$ for $500 \mathrm{~h}$ in wet air e $700{ }^{\circ} \mathrm{C}$ for $100 \mathrm{~h}$ in dry air f $700{ }^{\circ} \mathrm{C}$ for $100 \mathrm{~h}$ in wet air 
of adherent, uniform and dense $\mathrm{Al}_{2} \mathrm{O}_{3}$. In contrast, Fig. $4 \mathrm{e}, \mathrm{f}$ displays the presence of an outer oxide layer mixed with $\mathrm{TiO}_{2}$ (rutile) and $\mathrm{Al}_{2} \mathrm{O}_{3}$ crystals rather than a continuous $\mathrm{Al}_{2} \mathrm{O}_{3}$ layer after oxidation at $700{ }^{\circ} \mathrm{C}$ for $100 \mathrm{~h}$. The porosity of the oxide scale increased with increasing temperature and time. A multi-layered oxide scale was formed under dry conditions, consisting of $\mathrm{Al}_{2} \mathrm{O}_{3}$ at the gas/oxide scale interface and $\mathrm{TiO}_{2}$ at the oxide scale/substrate interface. Under wet conditions, the oxide scale did not show this typical layered structure. The distinction between $\mathrm{TiO}_{2}$ and $\mathrm{Al}_{2} \mathrm{O}_{3}$ was accomplished according to EPMA measurements which are not shown in this section. The presence of cracks was observable at the oxide scale/substrate interface in both dry and humid atmospheres.

Figure 5 shows the elemental mapping of the oxide scales and subsurface zone of the Ti-6Al-4V alloy after oxidation at $700{ }^{\circ} \mathrm{C}$ for $300 \mathrm{~h}$ in a dry atmosphere. The number of alternating $\mathrm{Al}_{2} \mathrm{O}_{3}$ and $\mathrm{TiO}_{2}$ layers increased and this multi-layered structure became more distinct for longer exposure times. However, under humid conditions $\mathrm{Al}_{2} \mathrm{O}_{3}$ and $\mathrm{TiO}_{2}$ layers did not follow an ordered pattern with distinct layers as seen in Fig. 6. Instead, $\mathrm{Al}_{2} \mathrm{O}_{3}$ appeared as a predominant phase in the outer oxide layer. In addition to the main oxide formers, vanadium doping of the rutile was observed in the oxide scales in both atmospheres. As demonstrated in Figs. 5 and 6, the growth of the oxide layer on the surface of Ti-6Al-4V was accompanied by the uptake of oxygen in the metal underneath the oxide layer (ODZ) due to the inward diffusion of oxygen in both atmospheres.

Distinctive nitridation was observed after oxidation at $700{ }^{\circ} \mathrm{C}$ for $500 \mathrm{~h}$ in dry air as shown in Fig. 7. However, the latter was absent in case of water vapor and at lower temperatures than $700{ }^{\circ} \mathrm{C}$ in dry air. SEM/EDX elemental mapping demonstrates that the reaction layer below the oxide layer consists of Al-rich and Aldepleted regions. The Al-depleted regions were instead enriched in nitrogen.
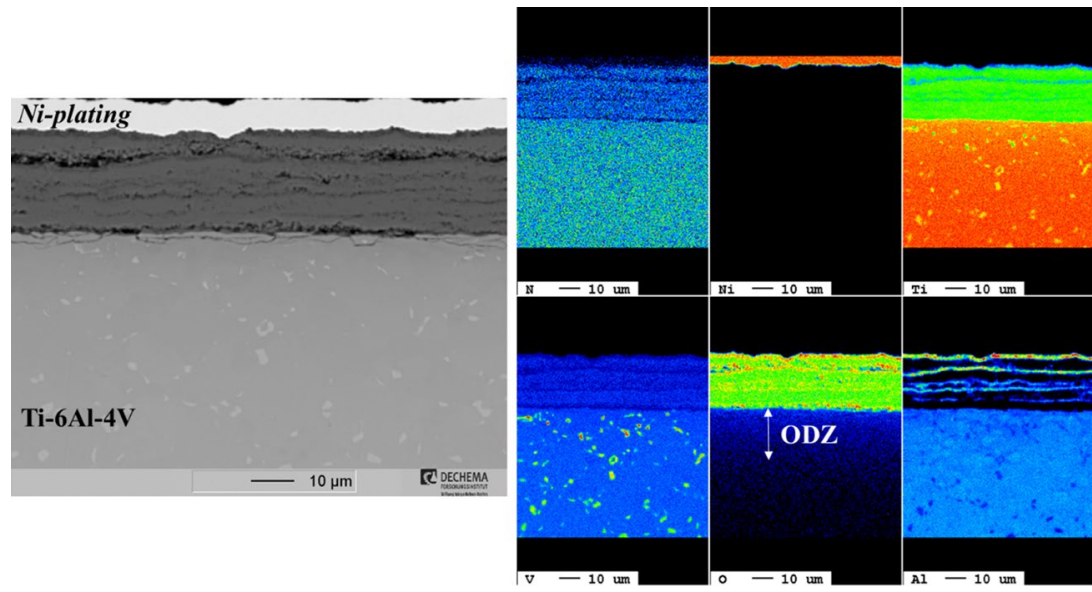

high

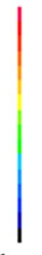

Fig. 5 BSE image of the sample oxidized at $700{ }^{\circ} \mathrm{C}$ for $300 \mathrm{~h}$ in dry air and corresponding elemental mapping of $\mathrm{N}, \mathrm{Ni}, \mathrm{Ti}, \mathrm{V}, \mathrm{O}$ and $\mathrm{Al}$ 


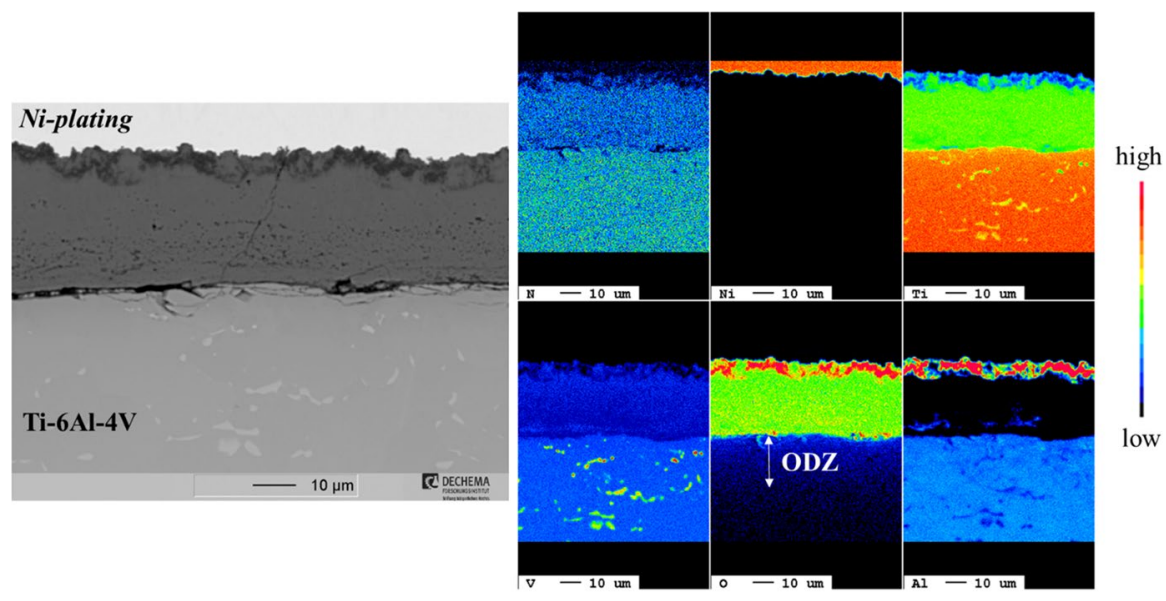

Fig. 6 BSE image of the sample oxidized at $700{ }^{\circ} \mathrm{C}$ for $300 \mathrm{~h}$ in wet air and corresponding elemental mapping of $\mathrm{N}, \mathrm{Ni}, \mathrm{Ti}, \mathrm{V}, \mathrm{O}$ and $\mathrm{Al}$
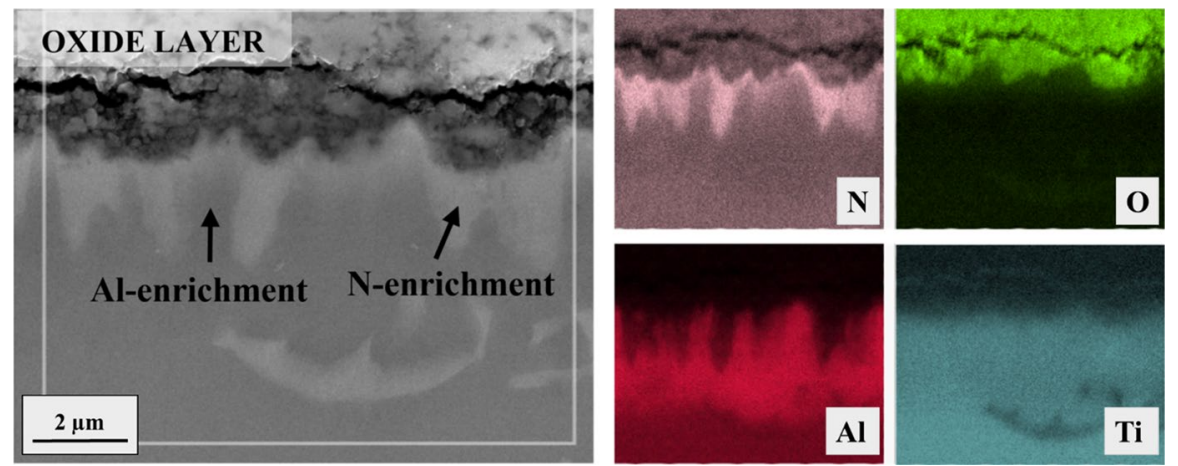

Fig. 7 SEM image and corresponding EDS element maps of the subsurface zone of the Ti-6Al-4V after oxidation at $700{ }^{\circ} \mathrm{C}$ for $500 \mathrm{~h}$ in synthetic air

\section{Alpha-Case Evaluation Technique}

\section{Nanoindentation Measurements}

At the surface, the hardness was highest and it exponentially decreased with increasing distance through the bulk ( 4.23 GPa). Hence, the alpha-case thickness could be assessed as the depth where the hardness value returned to the bulk hardness level. The boundary of the alpha-case layer was approximated by regression analysis on the indentation hardness $(\mathrm{GPa})$ vs. distance $(\mu \mathrm{m})$ as given in Fig. 8. The left boundary of the alpha-case layer is supposed to be the transition between oxide layer and substrate $(x=0)$ and the right boundary is defined as the hardness $\left(H N_{x}\right)$ where it reaches $110 \%$ of the value of the substrate $\left(H N_{o}\right)[21]$. 


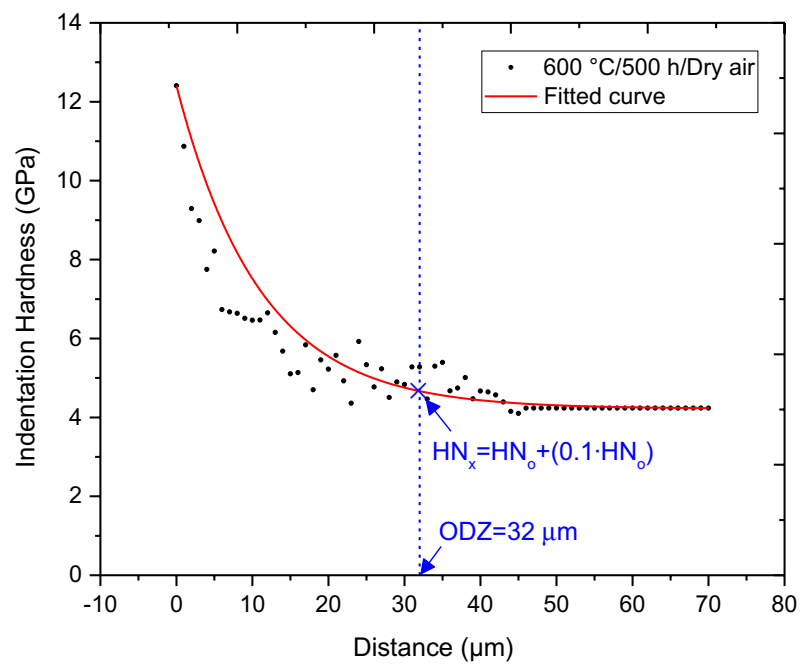

Fig. 8 Hardness profile along the thickness of the alpha-case for the Ti-6Al-4V sample oxidized for $500 \mathrm{~h}$ at $600{ }^{\circ} \mathrm{C}$ in dry air

$$
H N_{x}=H N_{o}+\left(0.1 \cdot H N_{o}\right)
$$

The approximated alpha-case thickness for the heat-treated sample at $600{ }^{\circ} \mathrm{C}$ for $500 \mathrm{~h}$ in dry air was found to be around $32 \mu \mathrm{m}$ as shown in Fig. 8. The ODZ was very narrow at $500{ }^{\circ} \mathrm{C}$ up to $300 \mathrm{~h}$ and thereby hardness measurements were carried out only on the samples oxidized at $500{ }^{\circ} \mathrm{C}$ for $500 \mathrm{~h}$ and 600 and $700{ }^{\circ} \mathrm{C}$ for 100,300 and $500 \mathrm{~h}$.

It was observed that the thickness of the alpha-case layer increased with increasing temperature and time in both atmospheres as shown in Fig. 9. Some of the ODZ was consumed by transformation into oxide; however it was not taken into consideration in the calculations due to the spallation shown in Fig. 2.

For 600 and $700{ }^{\circ} \mathrm{C}$, the diffusion coefficients and the activation energy for oxygen diffusion were assessed. The diffusion of oxygen was predicted using the typical diffusion length quantity $\sqrt{D t}$ in the thin-film solution (Gaussian solution) of Fick's second law [22]:

$$
x \sim \sqrt{D t}
$$

where $x$ is the alpha-case thickness in $\mu \mathrm{m}, D$ is the diffusion coefficient in $\mathrm{m}^{2} / \mathrm{s}$ and $t$ is the exposure time in h. The $D$ values were estimated by linear regression of the data given in Fig. 9 through calculation of the slope of the best fit line and are presented in Table 3.

In addition, the activation energy for diffusion of oxygen in the alpha-case layer was calculated using the Arrhenius equation [22]: 

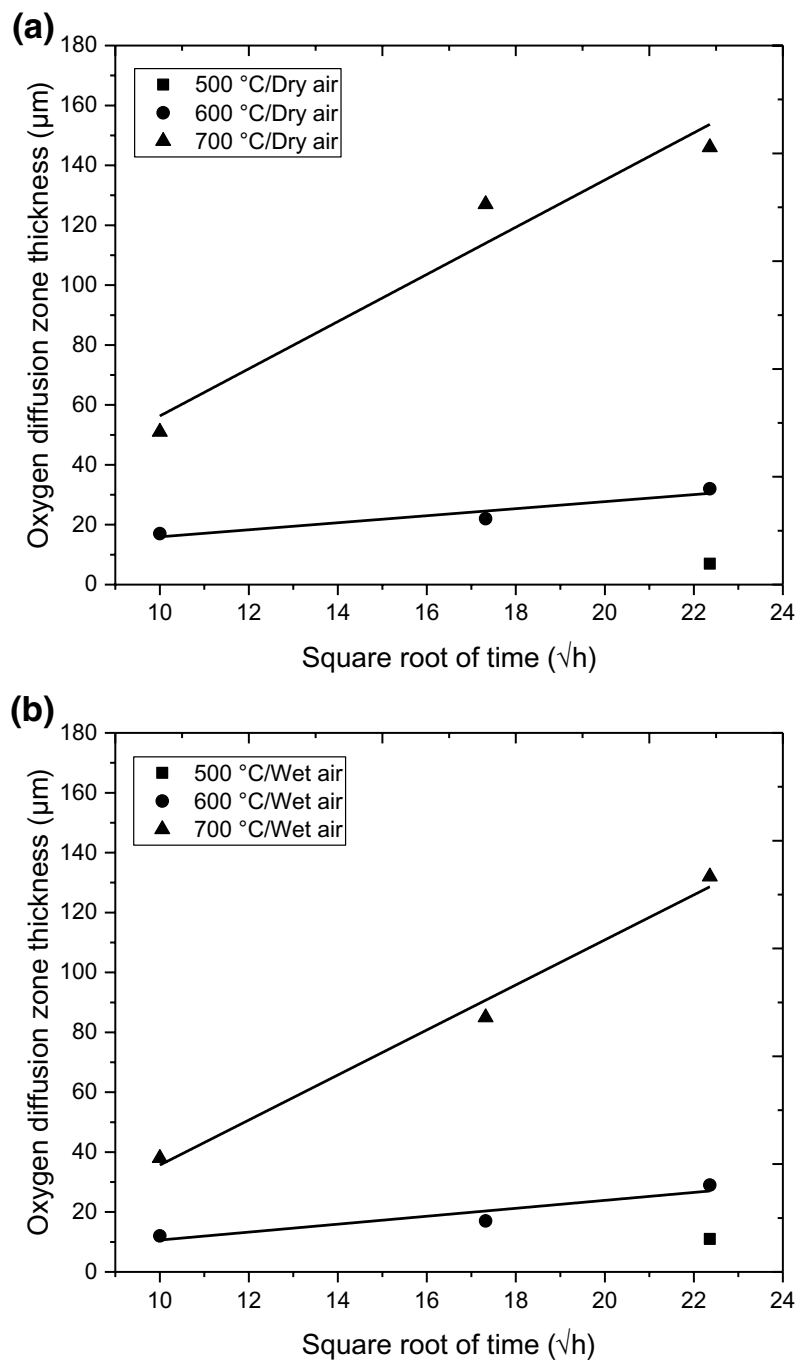

Fig. 9 ODZ thickness of the Ti-6Al-4V alloy as function of time in $\mathbf{a}$ dry air and $\mathbf{b}$ wet air

$$
D=D_{0} \exp \left(-\frac{Q_{\text {diffusion }}}{R T}\right)
$$

where $D_{0}$ is the pre-exponential factor, $Q_{\text {diffusion }}$ is the activation energy for diffusion of oxygen in the alpha-case layer, $R$ is the universal gas constant $(8.3143 \mathrm{~J} /(\mathrm{molK}))$ and $T$ is the temperature $(\mathrm{K})$. As a result, linear regression of $\ln D$ versus $1 / T$ data given in Fig. 10 provided the value of $-Q_{\text {diffusion }} / R$ by calculation of the negative slope of the best fit line. The linear fit of all the values obtained in this work (dry air) and in literature, using different evaluation techniques, is shown in short dashes in Fig. 10. Accordingly, $Q_{\text {diffusion }}$ for oxygen was found to be $217 \mathrm{~kJ} / \mathrm{mol}$. From this 


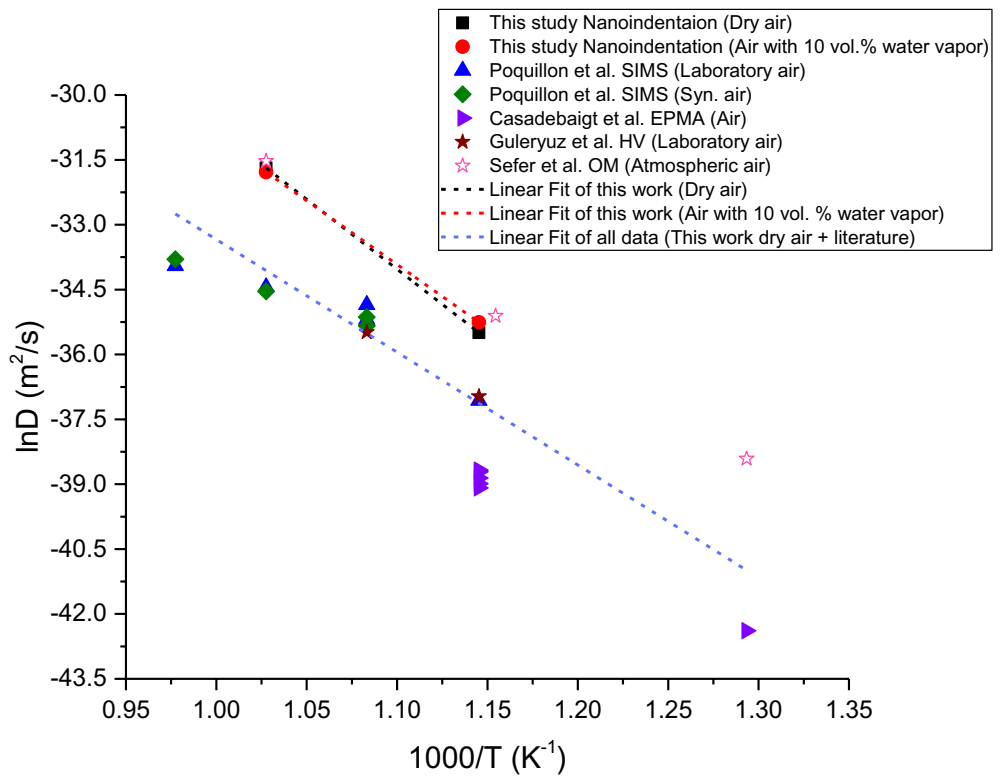

Fig. 10 Arrhenius plot of the diffusion of oxygen in Ti-6Al-4V [11, 12, 23, 24]

work, linear fits of values attained in dry and wet air are shown separately in Fig. 10. Consequently, $Q_{\text {diffusion }}$ values for oxygen in dry and wet air were found to be $269 \mathrm{~kJ} /$ mol and $245 \mathrm{~kJ} / \mathrm{mol}$, respectively, as shown in Table 2.

\section{Discussion}

\section{Influence of Water Vapor on The Oxide Scale Growth}

The simultaneous development of the oxide scale and diffusion of oxygen into the bulk material leads to a mass increase after oxidation in titanium alloys [25]. Kofstad [9] stated that time and/or temperature causes a transition in the laws of oxidation kinetics for pure titanium. At temperatures below $400{ }^{\circ} \mathrm{C}$, oxidation kinetics are logarithmic; from $400-500{ }^{\circ} \mathrm{C}$ they are cubic; from 600 to $1000{ }^{\circ} \mathrm{C}$ oxidation is parabolic; and above $1000{ }^{\circ} \mathrm{C}$ linear behavior is observed. In alloys, a transition

Table 2 Coefficients for diffusion of oxygen in Ti-6Al-4V at tested temperatures and the activation energy for diffusion of oxygen in both atmospheres

\begin{tabular}{llllll}
\hline & \multicolumn{2}{l}{ Diffusion coefficient D $\left(\mathrm{m}^{2} / \mathrm{s}\right)$} & & \multicolumn{2}{l}{$\begin{array}{l}\text { Activation energy Q } \\
(\mathrm{kJ} / \mathrm{mol})\end{array}$} \\
\cline { 2 - 3 } \cline { 5 - 6 } $\mathrm{T}\left({ }^{\circ} \mathrm{C}\right)$ & Dry air & Wet air & & Dry air & Wet air \\
\hline 600 & $3.84 \times 10^{-16}$ & $4.88 \times 10^{-16}$ & & 269 & 245 \\
700 & $1.73 \times 10^{-14}$ & $1.57 \times 10^{-14}$ & & \\
\hline
\end{tabular}


in the oxidation kinetics could also take place at lower temperatures for prolonged exposure times [9]. For instance, this type of transition was reported for pure titanium (at 732 and $760{ }^{\circ} \mathrm{C}$ ) [26], Ti-6Al-4V alloy (at $700{ }^{\circ} \mathrm{C}$ ) [12, 27], and Ti-60 alloy (at 700 and $750{ }^{\circ} \mathrm{C}$ ) [28], where the oxidation kinetics changed from parabolic to linear behavior after prolonged exposure times.

In the present study, the aforementioned oxidation behaviors could not be directly observed due to the oxide scale spallation as seen in Fig. 2. However, a clear difference between $500{ }^{\circ} \mathrm{C}$ and higher temperatures was observed. With water vapor exposure the oxide scale spalled off from the substrate after shorter times. The cause of the more severe spallation in the presence of water vapor (Fig. 3) was related to the adhesion between the oxide scale and the substrate, which turned out to be weaker in a humid atmosphere. A similar observation was made by Kremer et al. [29] for the oxidation rate of $\mathrm{Ti}-\mathrm{Al}$ in moist oxygen.

Figure 3a suggests a rippled oxide layer on the surface due to the agglomeration of the fine oxide grains along grinding lines after exposure in dry air at $600{ }^{\circ} \mathrm{C}$ for $100 \mathrm{~h}$. The oxides covered the entire alloy surface without an indication of oxide layer spallation. However, Fig. 3b shows agglomeration of the fine oxide grains along the grinding lines did not occur in the wet atmosphere. Instead, local clusters of fine oxide grains on the surface of the oxide layer were apparent. According to Fig. 3d, the oxide layer started to spall-off from the metal substrate in a water vapor atmosphere after $300 \mathrm{~h}$ of exposure time, which confirmed the weaker oxide layer adhesion to the substrate. As observed in Fig. 3f, a needle-like structure of $\mathrm{TiO}_{2}$ in wet air appeared on the surface after spallation, also proving that the spallation occurred during the test, not only upon cooling. In addition to full delamination, trough-cracking of the scale can be seen in Fig. $3 \mathrm{f}$.

From Fig. 4, the evolution of the scale at 600 and $700{ }^{\circ} \mathrm{C}$ can be seen. A dense oxide scale composed of a continuous $\mathrm{Al}_{2} \mathrm{O}_{3}$ scale formed at the gas/oxide interface after oxidation at $600{ }^{\circ} \mathrm{C}$ for $500 \mathrm{~h}$. However, the oxide scale was porous with a formation of mixed $\mathrm{TiO}_{2}-\mathrm{Al}_{2} \mathrm{O}_{3}$ at the gas/oxide interface after oxidation at $700{ }^{\circ} \mathrm{C}$ for $100 \mathrm{~h}$ as displayed in Fig. 4.

A very observable multilayered oxide scale of $\mathrm{Al}_{2} \mathrm{O}_{3}$ and $\mathrm{TiO}_{2}$ layers formed on the Ti-6Al-4V alloy in dry air, e.g., after exposure at $700{ }^{\circ} \mathrm{C}$ for $300 \mathrm{~h}$. After the same exposure temperature and time in wet air, $\mathrm{Al}_{2} \mathrm{O}_{3}$ solely precipitated in the outermost part of the rutile scale, with no indication of alumina deeper in the scale. This difference is clearly visible from the elemental mapping included in Figs. 5 and 6. Du et al. [14] described the growth mechanism of oxide scales formed on Ti-6Al$4 \mathrm{~V}$ that initiated with a thin $\mathrm{TiO}_{2}$ layer. Then, outward diffusion of $\mathrm{Al}^{3+}$ took place to form $\mathrm{Al}_{2} \mathrm{O}_{3}$ at the gas/oxide interface, whereas a reaction between oxygen and $\mathrm{Ti}^{4+}$ occurred at the oxide/substrate interface due to the inward diffusion of oxygen. Thus, a double-layered oxide scale was developed. After reaching a critical thickness of the oxide scale, accumulation of growth stresses at the oxide/substrate interface caused crack formation and correspondingly partial detachment of the oxide scale from the substrate. As a result, outward diffusion of $\mathrm{Al}^{3+}$ and $\mathrm{Ti}^{4+}$ diminished, while inward diffusion of oxygen dominated. When the oxygen pressure strongly increased, again a multi-layered scale was obtained [14]. Lower oxidation rates in dry air might be caused by the compact outer $\mathrm{Al}_{2} \mathrm{O}_{3}$ layer, which can act as a barrier 
for the oxygen transportation into the oxide. This result is in good agreement with that reported by Kremer et al. [29] for Ti-Al oxidized at $900{ }^{\circ} \mathrm{C}$ in dry and moist atmosphere.

To further understand this behavior, it is necessary to take the defect chemistry of the scale into account. Pure $\mathrm{TiO}_{2}$ is considered as both an oxygen-deficient (n-type) and a metal-deficient (p-type) oxide. The Kröger-Vink notation of defects (Table 3) can be used to define formation of defects by the resulting defect equilibria [30]:

$$
\begin{gathered}
O_{o}^{x}=V_{O}^{*}+2 e^{\prime}+\frac{1}{2} O_{2} \\
2 O_{o}^{x}+T i_{T i}^{x}=T i_{i}^{\cdots}+3 e^{\prime}+O_{2} \\
2 O_{o}^{x}+T i_{T i}^{x}=T i_{i}^{\cdots}+4 e^{\prime}+O_{2} \\
O_{2}=2 O_{o}^{x}+V_{T i}^{\prime \prime \prime \prime}+4 h
\end{gathered}
$$

The formation and transport of titanium vacancies (Eq. 7) take place much more easily at high temperatures [31]. During oxidation of titanium, the oxide scale was mainly formed by inward diffusion of oxygen [32], whereas the outward diffusion of $\mathrm{Al}^{3+}$ increased in the presence of water-vapor, leading to a change in the solubility of $\mathrm{Al}^{3+}$ in the $\mathrm{TiO}_{2}$ lattice. These phenomena can also be explained by a modification in the defect structure (n- to p-type) of Al-doped $\mathrm{TiO}_{2}$ due to the incorporation of water vapor [15]. The influence of water vapor on the oxide scale morphology after oxidation at $700{ }^{\circ} \mathrm{C}$ for $300 \mathrm{~h}$ is illustrated in Fig. 11.

\begin{tabular}{|c|c|c|}
\hline Notation & Meaning & $\begin{array}{l}\text { Kröger- } \\
\text { Vink } \\
\text { notation }\end{array}$ \\
\hline$T i_{T i}^{4+}$ & $T i^{4+}$ ion in the titanium lattice site & $T_{T i}^{x}$ \\
\hline$T i_{T i}^{3+}$ & $T i^{3+}$ ion in the titanium lattice site (quasi-free electron) & $e^{\prime}$ \\
\hline$A l_{T i}^{3+}$ & $A l^{3+}$ cation in the titanium lattice site & $A l_{T i}^{\prime}$ \\
\hline$V_{T i}$ & titanium vacancy & $V_{T i}{ }^{\prime \prime \prime \prime}$ \\
\hline$T i_{i}^{3+}$ & $T i^{3+}$ ion in the interstitial site & $T i_{i}$ \\
\hline$T i_{i}^{4+}$ & $T^{4+}$ ion in the interstitial site & $T i_{i}$ \\
\hline $\mathrm{O}_{\mathrm{o}}^{2-}$ & $O^{2-}$ ion in the oxygen lattice site & $O_{o}^{x}$ \\
\hline$V_{o}$ & oxygen vacancy & $V_{o}^{*}$ \\
\hline$O_{o}^{-}$ & $O^{-}$ion in the oxygen lattice site (quasi-free electron hole) & $h$ \\
\hline $\mathrm{OH}_{\mathrm{o}}^{-}$ & $O H^{-}$ion the oxygen lattice site & $\mathrm{OH}_{o}$ \\
\hline
\end{tabular}

The dissolution of hydrogen in the oxide affected the concentration of point defects in the oxide scale, which led to a change in the transport properties of the

Table 3 Kröger-Vink notation of the $\mathrm{TiO}_{2}$ lattice species [30] 
(a)



(b)

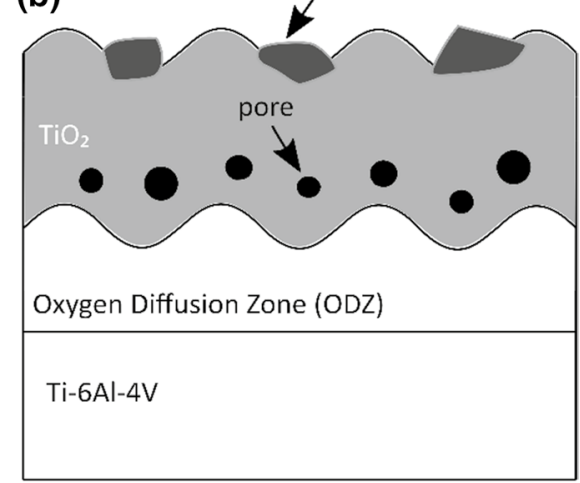

Fig. 11 Schematic representation of the oxide scale growth after exposure at $700{ }^{\circ} \mathrm{C}$ for $300 \mathrm{~h}$ in a dry air and $\mathbf{b}$ air with 10 vol. $\% \mathrm{H}_{2} \mathrm{O}$

scale [33]. In the presence of water vapor and in oxidizing conditions, the predominant defects in $\mathrm{TiO}_{2}$ are protons. The dissolution reaction of a water molecule is described by [34]:

$$
\mathrm{H}_{2} \mathrm{O}(\mathrm{g})+\mathrm{V}_{\mathrm{O}}^{*}+\mathrm{O}_{o}^{x}=2(\mathrm{OH})_{o}^{\dot{ }}
$$

where one oxygen vacancy is annihilated and two protons are formed. The protons are attached to oxygen ions on regular sites to form two hydroxide defects $(\mathrm{OH})_{o}^{\circ}$ [34]. Galerie et al. [35] suggested that the hydroxyl ions are transported similarly as oxide ions, which means $\mathrm{OH}^{-}$jumps from a substitutional site to an adjacent vacancy. The difference in transportation rate was then caused by a lower charge and smaller radius of hydroxyl ions than oxide ions [35]. Additionally, the concentration of protons was higher than that of oxygen vacancies. Both protons and oxygen vacancies were replaced by titanium vacancies leading to an increase in concentration of titanium vacancies [31]:

$$
2 \mathrm{H}_{2} \mathrm{O}+2 \mathrm{O}_{o}^{x}=\mathrm{V}_{T i}^{\prime \prime \prime \prime}+4(\mathrm{OH})_{o}
$$

This shows that the concentration of defects in the rutile scale formed in wet air is larger than that corresponding to the oxide scale formed in dry air. The observed formation of $\mathrm{Al}_{2} \mathrm{O}_{3}$ at the gas/oxide interface shown in Fig. 6 resulted from the outward diffusion of $\mathrm{Al}^{3+}$ through $\mathrm{TiO}_{2}$ via titanium vacancies. A similar observation was made by Maris-Sida et al. [36] concerning an increase in outward diffusion of nickel through the $\alpha-\mathrm{Al}_{2} \mathrm{O}_{3}$ scale via aluminum vacancies in the presence of water vapor. Additionally, as seen in Fig. 6, the accumulation of vacancies at the oxide/ metal interface led to the local formation of pores [37].

The dissolution of $\mathrm{Al}^{3+}$ into the $\mathrm{TiO}_{2}$ lattice can take place substitutionally and interstitially. Since $\mathrm{Al}^{3+}$ has a similar crystal ionic radii $\left(0.57\right.$ for $^{-3+}$ and $0.64 \AA$ for $\left.\mathrm{Ti}^{4+}\right), \mathrm{Al}^{3+}$ occupies regular $\mathrm{Ti}^{4+}$ sites and substitution is the main mechanism of solubility [38]. It can be represented for oxygen-deficient $\mathrm{TiO}_{2}$ as [39]: 


$$
A l_{2} O_{3}=2 A l_{T i}^{\prime}+V_{O}^{*}+3 O_{o}^{x}
$$

where for charge compensation, the $A l_{T i}^{\prime}$ is compensated by an oxygen vacancy $V_{O}^{.}$. Therefore, the concentration of oxygen vacancies in $\mathrm{TiO}_{2}$ increased. Alternatively, if protons are present, the following reaction can be proposed:

$$
\mathrm{Al}_{2} \mathrm{O}_{3}+\mathrm{H}_{2} \mathrm{O}=2 \mathrm{Al}_{\mathrm{Ti}}^{\prime}+2(\mathrm{OH})_{\mathrm{O}}^{\cdot}+2 \mathrm{O}_{o}^{x}
$$

As Zeller et al. [15] suggested, the formation of an outer oxide layer takes place by outward diffusion of cations and is possibly affected by the reaction of water vapor with $\mathrm{TiO}_{2}$. As a result, the precipitation behavior of $\mathrm{Al}^{3+}$ might alter due to a change in the defect structure by dissolution of $\mathrm{H}_{2} \mathrm{O}$ in $\mathrm{TiO}_{2}$ [15]. Experimental results showed that after exposure at $700{ }^{\circ} \mathrm{C}$ for $300 \mathrm{~h}$ in dry air, a continuous outer layer of $\mathrm{Al}_{2} \mathrm{O}_{3}$ was formed, which was not the case in a wet atmosphere. Consequently, due to the lattice diffusion of $\mathrm{Al}^{3+}, \mathrm{Al}_{2} \mathrm{O}_{3}$ particles precipitated in the outer part of the $\mathrm{TiO}_{2}$ scale. The concentration of metal vacancies in $\mathrm{TiO}_{2}$ became significant and dominant in humid air. The dissolution of $\mathrm{Al}^{3+}$ into a metal-deficient $\mathrm{TiO}_{2}$ lattice can be modified to:

$$
V_{T i}^{\prime \prime \prime \prime}+4(\mathrm{OH})_{O}^{\cdot}+2 \mathrm{Al}_{2} \mathrm{O}_{3}=4 A l_{T i}^{\prime}+4(\mathrm{OH})_{O}^{\cdot}+6 O_{o}^{x}
$$

where the titanium vacancies were removed and the solubility of $\mathrm{Al}^{3+}$ in $\mathrm{TiO}_{2}$ increased as shown in Fig. 12.

As shown in Fig. 7, oxidation in dry air at $700{ }^{\circ} \mathrm{C}$ for $500 \mathrm{~h}$ revealed a reaction layer at the interface between the oxide layer and the substrate. The reaction layer consisted of Al-rich and Al-depleted regions. Additionally, Al-depleted regions were enriched with nitrogen. According to Maeda et al. [40] a reaction layer between the oxide layer and substrate was observed after oxidation of Ti-6Al-4V at $737{ }^{\circ} \mathrm{C}$ for $144 \mathrm{~h}$ in air. XRD results of their study indicated that Al-rich and Al-depleted regions correspond to $\mathrm{Ti}_{3} \mathrm{Al}$ and $\alpha$ " phase (martensitic transformation of the $\beta$-phase during cooling), respectively. In the present study, a similar reaction layer was also present after oxidation in dry air. Moreover, elemental mapping by SEM indicates $\mathrm{N}$ enrichment in Al-depleted regions. Some authors examined an absence of $\mathrm{N}$

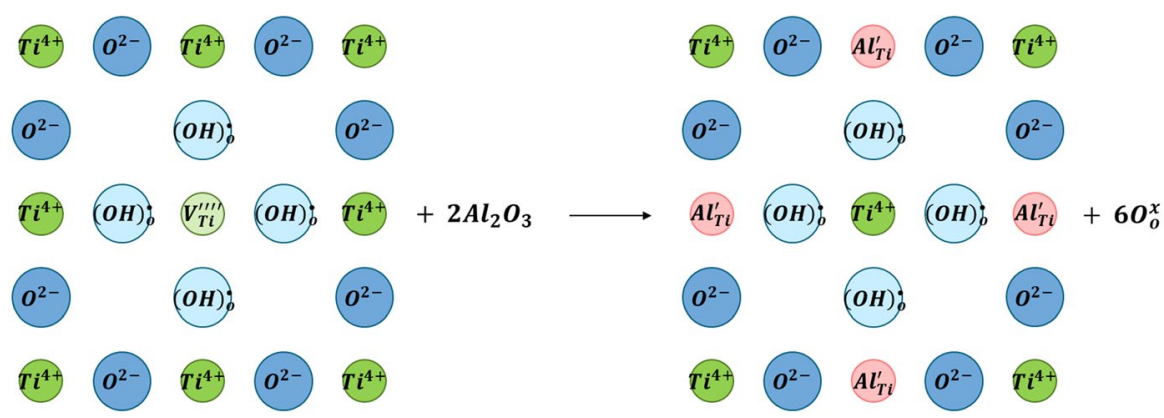

Fig. 12 Schematic illustration of the reaction between a metal-deficient $\mathrm{TiO}_{2}$ lattice and $\mathrm{Al}_{2} \mathrm{O}_{3}$ in the presence of water vapor 
enrichment at the interface after oxidation in water vapor. Michalik et al. [41] studied the oxidation of pure chromium in $\mathrm{N}_{2}-1 \% \mathrm{O}_{2}$ with and without different amounts of water vapor. The authors highlighted that the more polar and reactive $\mathrm{H}_{2} \mathrm{O}$ molecules avoid the permeation of nitrogen in the oxide scale, causing a suppression of internal nitridation [41]. Similar observations obtained in the present study were attributed to the aforementioned phenomena. It is important to note that vanadium was also present in the oxide scale and it might affect the defect chemistry, but no difference was found when comparing water vapor to dry air. Generally, vanadium has the ability to produce volatile species, such as $\mathrm{V}_{2} \mathrm{O}_{5}$. As a result, physical defects tend to occur in the oxide scale with the evaporation of the volatile vanadium species [11]. Accordingly, part of the porous structure in the oxide scale detected using EPMA might have been caused by vanadium. $V$ also influenced the defect chemistry, having various oxidation states; therefore, the presence of vanadium in the oxide scale should be investigated in future studies.

\section{Influence of Water Vapor on the Alpha-Casing Behavior}

Oxygen had the highest concentration at the surface and gradually decreased with increasing depth. It can be generalized that water vapor does not cause an obvious difference in the thickness of the ODZ. Diffusion coefficient $D$ values of two different temperatures $\left(600\right.$ and $\left.700{ }^{\circ} \mathrm{C}\right)$ were calculated for times up to $500 \mathrm{~h}$. Consequently, $Q_{\text {diffusion }}$ values for oxygen in dry and wet air were calculated as 269 and $245 \mathrm{~kJ} / \mathrm{mol}$, respectively. The Arrhenius plot shown in Fig. 10 presented that oxygen bulk diffusion rates at temperatures 600 and $700{ }^{\circ} \mathrm{C}$ were similar in dry and wet air. In the literature, comparable $Q_{\text {diffusion }}$ values for oxygen in dry atmosphere were reported by Frangini et al. (200 kJ/mol) [27], Guleryuz and Cimenoglu (202 kJ/ mol) [12] and Sefer et al. (215 kJ/mol) [11]. Correspondingly, the estimated $Q_{\text {diffusion }}$ value in this study was near to the activation energy for interstitial diffusion of oxygen in $\alpha-\mathrm{Ti}(200 \mathrm{~kJ} / \mathrm{mol})$ in the temperature range of $250-900{ }^{\circ} \mathrm{C}$ [42], which means for wet and dry air the principal mechanism for the alpha-case formation was the inward diffusion of oxygen in the alpha-phase.

\section{Conclusions}

The influence of water vapor on the oxide scale growth behavior and alpha-case formation during thermal oxidation of Ti-6Al-4V alloy were investigated within this study. The most important findings can be summarized as follows:

- The presence of water vapor promoted the oxide scale growth and accelerated the spallation of the oxide scale.

- While the oxide scale showed the typical layered $\mathrm{TiO}_{2} / \mathrm{Al}_{2} \mathrm{O}_{3}$ structure after exposure at $700{ }^{\circ} \mathrm{C}$ for $300 \mathrm{~h}$ in dry air, $\mathrm{Al}_{2} \mathrm{O}_{3}$ precipitates were present in the outermost part of the $\mathrm{TiO}_{2}$ scale in wet air. It is proposed that $\mathrm{H}_{2} \mathrm{O}$ increased the concentration of cation defects in the rutile layer and favored the outward diffu- 
sion of $\mathrm{Al}^{3+}$ and $\mathrm{Ti}^{4+}$. Due to the change in the defect structure of the rutile lattice, the solubility of $\mathrm{Al}^{3+}$ in $\mathrm{TiO}_{2}$ was influenced by water vapor.

- The extent of oxygen enrichment in the subsurface zone (alpha-case) was not considerably affected by the presence of water vapor in the atmosphere. The $Q_{\text {diffusion }}$ value for oxygen in dry and wet air was calculated as 269 and $245 \mathrm{~kJ} /$ mol, respectively.

Acknowledgements The financial assistance of the German Research Foundation (DFG) is gratefully acknowledged. The authors also thank Melanie Thalheimer and Dr. Gerald Schmidt from the DECHEMA Research Institute for the SEM and EPMA analysis.

Funding Open Access funding enabled and organized by Projekt DEAL.

Open Access This article is licensed under a Creative Commons Attribution 4.0 International License, which permits use, sharing, adaptation, distribution and reproduction in any medium or format, as long as you give appropriate credit to the original author(s) and the source, provide a link to the Creative Commons licence, and indicate if changes were made. The images or other third party material in this article are included in the article's Creative Commons licence, unless indicated otherwise in a credit line to the material. If material is not included in the article's Creative Commons licence and your intended use is not permitted by statutory regulation or exceeds the permitted use, you will need to obtain permission directly from the copyright holder. To view a copy of this licence, visit http://creativecommons.org/licen ses/by/4.0/.

\section{References}

1. N. Lin, R. Xie, J. Zou, et al., Surface damage mitigation of titanium and its alloys via thermal oxidation: A brief review. Reviews on Advanced Materials Science 58, 2019 (132-146).

2. J. Dai, J. Zhu, C. Chen, and F. Weng, High temperature oxidation behavior and research status of modifications on improving high temperature oxidation resistance of titanium alloys and titanium aluminides: A review. Journal of Alloys and Compounds 685, 2016 (784-798).

3. R. W. Evans, R. J. Hull, and B. Wilshire, The effects of alpha-case formation on the creep fracture properties of the high-temperature titanium alloy IMI834. Journal of Materials Processing Technology 56, 1996 (492-501).

4. G. Gautam, Thermal Oxidation of Ti6Al4V for Bio-Implementation (2011).

5. R. Gaddam, B. Sefer, R. Pederson, and M.-L. Antti, Oxidation and alpha-case formation in Ti-6Al2Sn-4Zr-2Mo alloy. Materials Characterization 99, 2015 (166-174).

6. R. Gaddam, B. Sefer, R. Pederson, and M.-L. Antti, Study of alpha-case depth in Ti-6Al-2Sn-4Zr2Mo and Ti-6Al-4V. IOP Conference Series: Materials Science and Engineering 48, 2013 (12002).

7. S. Patankar, M. J. Tan, Influence of alpha casing on superplastic deformation of Ti6Al4V. Journal of Engineering Materials and Technology 123, (2001).

8. H. Wu, Oxygen diffusion through titanium and other HCP metals 3, (2013).

9. P. Kofstad, High temperature corrosion (1988).

10. J-M. Oh, B-J. Lee, S. Cho, S. Lee, C. Good-Sun, L. Jae Won, Oxygen effects on the mechanical properties and lattice strain of Ti and Ti-6Al-4V. Metals and Materials International 17, (2011).

11. B. Sefer, Oxidation and Alpha-Case Phenomena in Titanium Alloys used in Aerospace Industry: $\mathrm{Ti}-6 \mathrm{Al}-2 \mathrm{Sn}-4 \mathrm{Zr}-2 \mathrm{Mo}$ and $\mathrm{Ti}-6 \mathrm{Al}-4 \mathrm{~V}$.

12. H. Guleryuz and H. Cimenoglu, Oxidation of Ti-6Al-4V alloy. Journal of Alloys and Compounds 472, 2009 (241-246).

13. E. V. Naydenkin, I. P. Mishin, I. V. Ratochka, O. N. Lykova, O. V. Zabudchenko, The effect of alpha-case formation on plastic deformation and fracture of near $\beta$ titanium alloy. Materials Science and Engineering A. 769, 138495 (2020). 
14. H. L. Du, P. K. Datta, D. B. Lewis, and J. S. Burnell-Gray, Air oxidation behaviour of Ti-6Al-4V alloy between 650 and $850^{\circ}$. Corrosion Science 36, 1994 (631-642).

15. A. Zeller, F. Dettenwanger, and M. Schütze, Influence of water vapour on the oxidation behaviour of titanium aluminides. Intermetallics 10, 2002 (59-72).

16. F. Motte, C. Coddet, P. Sarrazin, M. Azzopardi, and J. Besson, A comparative study of the oxidation with water vapor of pure titanium and of Ti-6Al-4V. Oxidation of Metals 10, 1976 (113-126).

17. S. Wang, Z. Liao, Y. Liu, and W. Liu, Influence of thermal oxidation temperature on the microstructural and tribological behavior of Ti6A14V alloy. Surface and Coatings Technology 240, 2014 (470-477).

18. ASTM titanium specifications. American Society for Testing and Materials (1993).

19. N. Prasad, R. Wanhill , Aerospace Materials and Material Technologies: Volume 1: Aerospace Materials (2017).

20. W. C. Oliver and G. M. Pharr, An improved technique for determining hardness and elastic modulus using load and displacement sensing indentation experiments. Journal of Materials Research 7, 1992 (1564-1583).

21. M. Mosbacher, V. Shaker, Oxidations-und Sauerstoffdiffusionsverhalten der Zirconiumlegierung ZrNb7 für tribologische Anwendungen. Shaker (2020).

22. H. Mehrer, Diffusion in solids: Fundamentals, methods, materials, diffusion-controlled processes, (Springer, Berlin, 2007).

23. D. Poquillon, C. Armand, J. Huez, Oxidation and oxygen diffusion in Ti-6Al-4V alloy: improving measurements during sims analysis by rotating the sample, in 8th International Symposium on High-Temperature Corrosion and Protection of Materials. (2012).

24. A. Casadebaigt, J. Hugues, D. Monceau , High temperature oxidation and embrittlement at 500$600{ }^{\circ} \mathrm{C}$ of Ti-6Al-4V alloy fabricated by laser and electron beam melting. Corrosion Science 175, 108875 (2020).

25. G. Fargas, J. Roa, B. Sefer, R. Pederson, M-L. Antti, A. Mateo, Oxidation behavior of Ti-6Al-4V alloy exposed to isothermal and cyclic thermal treatments. Conference Paper (2017).

26. J. Unnam, R. N. Shenoy, and R. K. Clark, Oxidation of commercial purity titanium. Oxidation of Metals 26, 1986 (231-252).

27. S. Frangini, A. Mignone, and F. De Riccardis, Various aspects of the air oxidation behaviour of a Ti6Al4V alloy at temperatures in the range 600-700 ${ }^{\circ} \mathrm{C}$. Journal of Materials Science 29, 1994 (714-720).

28. W. Jia, W. Zeng, X. Zhang, Y. Zhou, J. Liu, and Q. Wang, Oxidation behavior and effect of oxidation on tensile properties of Ti60 alloy. Journal of Materials Science 46, 2011 (1351-1358).

29. R. Kremer and W. Auer, Influence of Moisture on the Oxidation of gamma-TiAl Einflu $\beta$ von Wasserdampf auf die Oxidation von gamma-TiAl. Materials and Corrosion 48, 1997 (35-39).

30. M. K. Nowotny, L. R. Sheppard, T. Bak, J. Nowotny, Defect chemistry of titanium dioxide. Application of defect engineering in processing of $\mathrm{TiO}_{2}$-based photocatalysts. The Journal of Physical Chemistry C 112, 5275-5300 (2008).

31. J. Nowotny, T. Norby, T. Bak, Reactivity between titanium dioxide and water at elevated temperatures. The Journal of Physical Chemistry C 114 (2010).

32. S. Becker, A. Rahmel, M. Schorr, and M. Schütze, Mechanism of isothermal oxidation of the intermetallic TiAl and of TiAl alloys. Oxidation of Metals 38, 1992 (425-464).

33. M. Obigodi-Ndjeng, High Temperature Oxidation and Electrochemical Investigations on Ni-base Alloys (2011).

34. Waser R. Proton solubility in undoped and Fe-doped SrTiO3: temperature dependence and formation of defect associates 42, 1357-1365 (1987).

35. A. Galerie, Y. Wouters, and M. Caillet, The kinetic behaviour of metals in water vapour at high temperatures: Can general rules be proposed? Materials Science Forum 369-372, 2001 (231-238).

36. M. C. Maris-Sida, G. H. Meier, and F. S. Pettit, Some water vapor effects during the oxidation of alloys that are $\alpha-\mathrm{Al} 2 \mathrm{O} 3$ formers. Metallurgical and Materials Transactions A 34, 2003 (2609-2619).

37. D. Zhu, X. Wang, J. Zhao, et al., Effect of water vapor on high-temperature oxidation of NiAl alloy. Corrosion Science 177, 108963 (2020).

38. R. A. Slepetys and P. A. Vaughan, Solid solution of aluminum oxide in rutile titanium dioxide. The Journal of Physical Chemistry 73, 1969 (2157-2162).

39. J. Stebbins, Aluminum substitution in rutile titanium dioxide: new constraints from high-resolution 27Al NMR. Chemistry of Materials 19 (2007). 
40. K. Maeda, S. Suzuki, K. Ueda, et al., Experimental and theoretical study of the effect of Si on the oxidative behavior of Ti-6Al-4V alloys. Journal of Alloys and Compounds 776, 2019 (519-528).

41. M. Michalik, S. L. Tobing, M. Hänsel, V. Shemet, W. J. Quadakkers, D. J. Young, Effects of water vapour on the high temperature nitridation of chromium. Materials and Corrosion (2013).

42. Z. Liu and G. Welsch, Literature survey on diffusivities of oxygen, aluminum, and vanadium in alpha titanium, beta titanium and in rutile. Metallurgical Transactions A 19, 1988 (1121-1125).

Publisher's Note Springer Nature remains neutral with regard to jurisdictional claims in published maps and institutional affiliations. 